\title{
FACTORS ASSOCIATED WITH INCREASED RISK OF OVERWEIGHT AND OBESITY IN CHILDREN: AN EVIDENCE FROM BOYOLALI, CENTRAL JAVA
}

\author{
Dwi Wijayanti'), Harsono Salimo²), Yulia Lanti Retno Dewi3) \\ 1)Masters Program in Public Health, Universitas Sebelas Maret \\ ${ }^{2)}$ Department of Pediatrics, Dr. Moewardi Hospital, Surakarta \\ 3)Department of Nutrition, Faculty of Medicine, Universitas Sebelas Maret
}

\begin{abstract}
Background: Childhood obesity is a major public health challenge both in developed and developing countries. The prevalence of childhood obesity has increased over few years. It is caused by imbalance between calorie intake and calories utilized. One or more factors (genetic, behavioral, and environmental) cause obesity in children. This study aimed to examine factors associated with increased risk of overweight and obesity in children in Boyolali, Central Java.

Subjects and Method: This wasa case control study carried out at 25 primary schools in Ngemplak sub-district, Boyolali, Central Java. A sample of 200 students was selected by fixed disease sampling. The dependent variable was overweight/obesity. The independent variables were nutritional intake, physical activity, pocket money, paternal education, maternal and paternal nutritional status. The data were collected by questionnaire and analyzed by a multiple logistic regression.

Results: High nutritional intake $(\mathrm{OR}=21.48 ; 95 \% \mathrm{CI}=9.82$ to $47.98 ; \mathrm{p}=0.003)$, low physical activity $(\mathrm{OR}=23.72 ; 95 \% \mathrm{CI}=11.2$ to $50.26 ; \mathrm{p}=0.005)$, much pocket money $(\mathrm{OR}=40.44 ; 95 \% \mathrm{CI}=17.42$ to $93.88 ; \mathrm{p}=0.005)$, high paternal education $(\mathrm{OR}=4.04 ; 95 \% \mathrm{CI}=2.12$ to $7.69 ; \mathrm{p}=0.019)$, overweight mother $(\mathrm{OR}=84.86$; $95 \% \mathrm{CI}=25.62$ to $164.17 ; \mathrm{p}=0.001)$, and overweight father $(\mathrm{OR}=16.62 ; 95 \% \mathrm{CI}=$ 8.21 to $33.63 ; \mathrm{p}=0.003$ ) were associated with an increased risk of overweight/ obesity among primary school students. Nagelkerke $\mathrm{R}^{2}=94.1 \%$.

Conclusion: High nutritional intake, low physical activity, much pocket money, high paternal education, overweight mother, and overweight father, are associated with an increased risk of overweight/ obesity among primary school students.
\end{abstract}

Keywords: overweight, obesity, nutritional intake, physical activity, pocket money

\section{Correspondence:}

Dwi Wijayanti. Masters Program in Public Health, Universitas Sebelas Maret. Jl. Ir. Sutami No. 36A, Surakarta 57126, Central Java.

Email: dwijaymail@gmail.com. Mobile:+6285642214066.

The 4th International Conference on Public Health

Best Western Premier Hotel, Solo, Indonesia, August 29-30, 2018 | 212 https://doi.org/10.26911/theicph.2018.03.43 